\title{
Criminal Liability of Legal Persons for Food Adulteration Crime in UAE Law
}

\author{
Dr. Ezzat Mohamed Al Emary \\ Assistant Professor, Faculty of Law \\ Al Falah University, Dubai (UAE)
}

\begin{abstract}
To apply some ideas about the criminal liability of legal persons for the food adulteration crime in the Emirati law as we explain and clarify the conditions for proving this liability as it is necessary that the committed act shall be included within the acts constituting the food adulteration crime, that the same crime shall be committed by one of the legal person's bodies or representatives and that the same crime shall be finally committed for the account and in the name of legal person. However, the criminal liability of legal person shall be proven and established in parallel with the natural person's liability to ensure the control of food adulteration crime so that the legal person's liability shall not constitute a veil to cover the liability of natural person for committing this criminal act.
\end{abstract}

Keywords: Criminal Liability, Legal Persons, Food Crime, Emirati Law

\section{Introduction}

\section{Research Subject:}

The general rule is that only the natural person shall be responsible for crime. The will, which is the principal constituent of the moral pillar, is only for the natural person. However; due to the expansion of activity circle of the legal persons in modern times as a result of the development that took place in all economic, social and technological fields which sometimes became the source of many crimes (such as economic crimes and violations of labor law), it should think that the legal persons shall be criminally responsible for the crimes committed for the purpose of carrying out their activities, especially economic activities. It is not limiting only to punish natural persons who commit such crimes while carrying out their work with the legal persons.

\section{Research Importance:}

In fact, the criminal protection of the consumer is the most important aspect of the legal protection of the consumers. It is the protection that the legislator is relied on when he decides the inadequacy or lack of the protection prescribed in other legislations or when he aims at protecting an economic policy applied for the benefit of the public due to the lack of civil protection for the following reasons

1. The civil protection assumes practically the existence of a contract made between the producer or distributor and the consumer as the civil protection is provided only to consumer contractors.

2. The circle of freedom of contracting has receded at the time being under the pressure of globalization and the rapid growth of multinational companies that exploit their monopoly to the large areas of economy.

In pursuance thereof, the Federal Law No. (4) of 1979AD which criminalized acts of commercial fraud in commercial transactions is issued. In order to follow-up the development of fraud means, methods and its expansion, the legislator issued the Federal Law No. 19 of 2016AD to control commercial fraud which abrogated the previous Law No. 4 of 1979AD.

\section{Previous studies:}

Several studies have been made to discuss the criminal liability of legal persons; including but not limited to, Dr. Sherif Sayed Kamel: The Criminal Liability of the Legal Persons, Dar alNahda al-Arabiya, First Edition, 1997AD, Dr. Omar Salem: The Criminal Liability of the Legal Persons, Dar al-Nahda al-Arabiya, First Edition, 1995AD, Dr. Adbulrazaq Al Muwafy: Criminal Liability of Economic Establishment's Manager, Doctoral Thesis, Faculty of Law, Mansoura University, 1999AD.

However, no previous study; to my best knowledge, has specifically discussed about the Criminal Liability of legal persons for food adulteration crime. 


\section{Search Issues:}

The research subject matter raises many issues as follows: Issues arise in determining the conditions which should be applied to prove and establish the criminal liability of the legal person for food adulteration crime, the impacts of this liability which influence the liability of the natural person and the penalties applied against the legal person and appropriate for his nature.

In this research, we will try to answer these questions and develop clear solutions thereto.

\section{Research Approach:}

The analytical approach is one of the legal academic research methods, in which the researcher starts from the general rule applied to the partial cases.

Our study will be based on the analytical approach that stems from the criminal liability, which is borne by the legal persons and applied against the food adulteration crime.

\section{Research Plan:}

Based on the above, we shall divide the research according to the following:

First Theme: Liability of Legal Persons in the Economic Penal Code.

Second Theme: Conditions for Proving the Criminal Liability of Legal Persons for Food Adulteration Crime.

Third Theme: Impacts of the Liability of Legal Persons on the Liability of Natural Person.

Fourth Theme: Penalties Applied against the Legal Person for Food Adulteration Crime.

\section{First Theme}

\section{Liability of Legal Persons in the Economic Penal Code}

\section{First: Jurisprudence Opinion:}

If the Criminal Liability of legal persons has caused widespread controversy among criminal law jurists in the field of ordinary crimes, the prevailing opinion is to recognize this liability within the scope of economic crimes, based on several considerations which can be summarized as follows:

1. The majority of economic crimes are committed for the purpose of financial benefits. These benefits are distributed to each person who has a share in the legal person. Thus, the penalty must be applied against the legal person and affected on his money and his activity because the limitation of punishment effects on the natural person will not be feasible for the following two reasons: 1. His wealth shall not often allow to cover the financial sanctions applied against the crime, 2. The punishments applied against him will not prevent the repetition of the offenses committed by the legal person.

2. The argument of denying the criminal liability of legal persons upon which the legal experts are based on is the lack of the sinful will. This argument is not valid in economic crimes as the criminal intent diminishes a lot in economic crimes and the crime is achieved once the criminal act constituting the same crime is committed with no need to search for the availability of criminal intent. In addition, the freedom of choice, which the theory of criminal liability is generally based on, is found to be fully applied to many legal persons, through discussions held in the meetings of Boards of Directors of the commercial companies.

3. The opinion, sees that it is not permissible to apply the penalties against the legal person, is not found in the Economic Penal Law imposing a special kind of penalties; including financial sanctions, fines, confiscation, closure and the like, on the legal person. Moreover, the idea of satisfaction or correction of an offence is not noticed in many of the penalties stipulated in the Economic Penal Code. However, the motivation thereof is to protect or take preventive measures so that the crime shall not occur in the future. Furthermore, the precautionary measures find a fertile ground to be applied in the Economic Penal Code as it does not require the normal conditions of criminal liability.

Second: Opinion of UAE Legislator:

The UAE legislator has taken the modern approach in jurisprudence and comparative law calling for the recognition of criminal liability of legal persons as the Article 65 of Federal Law No. (3) of 1987AD set out in the Penal Code amended by the Federal Law No. (7) of 2016AD stipulates that the legal persons, except for the government bodies, its official departments, public authorities and institutions are criminally liable for the crimes committed by their representatives, directors 
or agents for or on behalf thereof. No penalty may be applied against them other than fine, confiscation and criminal measures established by law against crime. In case the law stipulates that an original penalty other than fine shall be applied against crime, the penalty shall be limited to a fine not exceeding a maximum amount of five hundred thousand dirhams as such matter shall not prevent the application of penalties prescribed by law against the perpetrator personally.

It follows from the provision that the legislator has established a general rule determining the liability of legal person towards the crimes committed within the scope of his work. Therefore, the liability of natural person shall not be limited to the natural person who may be the legal person's representative, manager or agent.

The provision ruled that the legislator has adopted the principle of criminal liability of the legal person as per the Article 65 of Penal Code indicating the duplication of criminal liability held for the single criminal act which means that both the legal person and natural person may be simultaneously liable for the same criminal act in case the pillars of that liability are available.

The provision ruled also that the provision of Article 65 of Penal Code states that this provision is deemed as an exception to the general rule of criminalization, i.e. "punishment", as the legislator has established the punishments as an original rule to be applied against the natural persons found guilty and to say that the legal person has nothing to prevent it from being punished in case he violates the law which constitutes a criminal act. Therefore, the legislator obligates the legal person's responsible officers to behave properly in performing their work to avoid future punishment. The liability of legal person is mainly based on the assumed liability in accordance with the Article 65.

The legislator decided about the food adulteration crime that the criminal liability is borne by the legal person for the crime in accordance with the First Article of Federal Law No. 19 of 2016AD issued to control the commercial fraud which defined the trader as any natural or legal person acting on his behalf and for his account in the commercial businesses specified in the Commercial Transactions Law, engaging in commercial activity, taking one of the forms provided for in the Commercial Companies Law even if the activity carried out by natural or legal person is deemed as a civil activity, informing the public in any way about an activity established thereby for trade or becoming a professional trader under fictitious name, disguising or hiding behind another person. It also defined the establishment as any institution, company or any other entity constituting any legal form whatsoever through which the economic activity shall be practiced in the country.

Therefore, it follows from this Article that the legal persons who shall be criminally liable are as follows:

1- All companies incorporated and established in accordance with the provisions stipulated in the Commercial Companies Law even if they consist of one person, or the activity carried out thereby is deemed as a commercial, financial, industrial, agricultural, real estate activity or other economic activity.

2- All companies deemed as invalid companies in accordance with the provisions set out in the Companies Law provided that they start the implementation of any activity announced to the public.

\section{Second Theme}

\section{Conditions for proving the Criminal Liability of Legal Persons for Food Adulteration Crime}

We can say that there are certain conditions which must be applied to prove the criminal liability of an economic establishment (such as a legal person) for the food adulteration crime. These conditions can be divided into two conditions as follows:

The first condition is relating to the person who commits the crime such as anyone of the legal person's bodies or representatives and the second condition is relating to the person for which this crime is committed, i.e. this crime is committed in favor of the legal person itself. There is a prerequisite condition that the acts committed by the legal person shall be included within the acts constituting the food adulteration crime. We shall discuss all these three conditions in detail as follows: 
First, Act committed and included within the Acts constituting the Food Adulteration Crime:

It is necessary to litigate the legal person about the food adulteration crime in case the committed acts shall be included within the acts constituting the food adulteration crime stipulated and limited by the legislator in the Article (1) of Federal Law No. 19 of 2016AD to control the commercial fraud defined as the deception of anyone of dealers in any manner whatsoever by replacing, changing the nature, amount, type, price, essential quality, origin country, exporter or validity of goods or any matter relating thereto or providing incorrect or deceptive commercial data about the promoted products including the deception, imitation and fraud which may be inconsistent with the laws applicable in the country or including false or deceptive data.

It follows from the previous provision that the foodstuffs shall be deemed as adulterated or corrupted foodstuffs in the following cases:

1. The lack of availability of any of the specifications and conditions which must be applied in relation to the foodstuffs or in case it shall prejudice to the same foodstuffs either by amending the specifications and conditions through deletion or addition in any form whatsoever.

2. In case the foodstuffs have no nutrition value and are not valid to be consumed by people or they shall be considered as one of the foodstuffs prohibited by law.

3. In case the foodstuff's nutritive additions are harmful to the health in case they are prohibited by law and in case they are not consistent with the specifications and conditions.

4. In case the data described in the foodstuff's labels are violated as they contain incorrect, illusive or deceptive data indicating directly or indirectly that it is another foodstuff, leading in any form whatsoever to an incorrect impression about its nature and characteristic or leading to the confusion between the same product and other products.

5. In case the health conditions stipulated by the foodstuffs' factories and their employees and set out in the standard specifications are violated.

6. In case the conditions of manufacturing, packing, transporting, cooking or offering these foodstuffs are violated.

The provision ruled that the legal persons are criminally liable for crimes committed by its representatives, directors or agents for or on behalf thereof, i.e. there is a positive act committed by those persons and deemed as a crime committed for or on behalf thereof and any activity which is intentionally done in relation to the acts committed for the company's interests and benefits.

Second, Crime committed by one of the Establishment's Natural Persons or Representatives:

The Article (65) of the Federal Law No. (3) of 1987AD set out in the Penal Code amended by the Federal Law No. (7) of 2016AD stipulates that "the legal persons except the governmental authorities, their official departments, public bodies and institutions shall be criminally liable for the crimes committed by their representatives, managers or agents on behalf or in name thereof ...".

The establishment's natural persons shall include one or more natural persons authorized by virtue of the law or company's articles of association to manage the financial corporation and act on behalf thereof such as the general assembly, board of directors, board of control and governing body. Its representatives shall include the persons having the powers to practice the establishment's activities on behalf thereof such as the general manager, chairman of the board of directors or chief executive officer.

The research raises about proving the criminal liability of legal person whether the food adulteration crime is committed by one of the legal person's employees or not. An opinions sees that the legal person shall not be criminally liable for the crime committed by one of its employees who have not been authorized by one of the legal person's bodies or representatives.

However, the liability of legal person is expanded by the Federal Court even if a normal employee commits the act. The Federal Court also sees that a certain capacity of a 
natural person is deemed as a condition for a duplicated liability held by both the latter and legal person.

The provision ruled that the duplication of criminal liability for the single criminal act shall mean that both the legal person and natural person may be simultaneously liable for the same criminal act if the pillars of that liability are available. However, a certain capacity must be owned by the natural person in accordance with the principle of inability of analogy and lack of expansion of the interpretation of criminalization texts based on the principle of legitimacy of crimes and penalties to hold the duplicated liability rather than he shall be a representative, director or agent of this legal person and that the act is committed for or on behalf of this person. Thereupon; in case the person who commits the criminal act shall not have any of the aforementioned capacities, in case he shall be deemed as a normal employee of the legal person and in case he shall not be deemed as his representative, director or agent, such matter shall not prevent the legal person from being criminally liable despite the legal person becomes innocent in case he shall not have any of the aforementioned capacities, i.e. he is a normal employee working in the different departments of company. Moreover, it is sentenced that this legal person is innocent.

The provision also ruled that the law allows for the litigation of legal persons and that in case either the name of legal person's responsible officer is determined or not in the referral order, such matter shall not be necessary as long as the judgment determines the identity of supervisor of the site where the incident occurs.

We see that the criminal liability of legal person is expanded by the Federal Court for the criminal act without requiring a certain capacity of the natural person working with him or having a certain task, although the Article (65) of Penal Code was obvious and clear about the necessity of availability of such matter to prove the legal person's liability.

Third, Crime committed for or on behalf of the Legal Person:

To prove the criminal liability of a legal person, the food adulteration crime must be committed for or on behalf of this legal person as it is not sufficient that the adulteration act is committed by one of the responsible officers, but also the same act must be committed for and on behalf of this legal person.

In fact, one of the establishment's natural persons or representatives may act in this capacity for his personal benefit or for the benefit of others. Thus, these acts shall not be deemed as acts committed for or on behalf of the legal person, despite these acts are committed by its representatives or legal persons. Therefore, it is decided that the act is committed for or on behalf of the legal person in case the same is committed within the limits of duties assigned to the establishment's legal person or representative for the regular workflow thereof and its final goal is to achieve its material or moral purposes.

\section{Third Theme:}

\section{Impacts of the Legal Person's Liability on}

\section{the Natural Person's Liability}

The Article (65) of the Penal Code stipulates that the legal persons, except for the government bodies, its official departments, public authorities and institutions, are criminally liable for crimes committed by its representatives, directors or agents for or on behalf thereof. Such matter shall not prevent from punishing the perpetrator personally by the penalties prescribed by law.

It follows from this provision that the legal person's criminal liability shall not prevent the natural persons who are working for the establishment from being litigated. In case the manager of a company dealing with the foodstuffs frauds or adulterates these foodstuffs, the company's liability for the food adulteration shall not prevent this manager from being litigated about this crime.

Thus, the liability of natural persons who express the establishment's will and commit acts for and on behalf thereof shall not be excluded once the criminal liability of establishment itself is established and proven for the following considerations:

1. It is logical to prove the criminal liability of an establishment that there is a certain natural person or persons having the power to act for or on behalf thereof and committing the crime for or on behalf thereof. Whereas the crime committed for or on behalf of others shall not be deemed a reason for the denial of perpetrator's responsibility, it is normal to 
litigate both the legal person and natural person committing this crime upon the availability of conditions required by law.

2. To ensure that both the food adulteration crime and punishment effectiveness are followed-up, the proven criminal liability of establishment shall not constitute a veil to cover the personal liability of natural persons committing the crime. It shall not be pretested that they commit these acts for and on behalf of the legal person or for its benefit to escape from punishment because this benefit shall be often deemed as the benefit of those persons who are partners or shareholders of this legal person.

The manager shall mean both the chairman of board of directors of the stock companies and manager of individual companies. However, it is not necessary that the actual manager is deemed as the person appointed in accordance with the articles of association of a legal entity. The actual manager shall be deemed as the person who implements the acts of legal manager, exercising his powers and acting solely on behalf of this latter or by agreement with this latter provided that his opinion shall have no legal effect or force.

Therefore, the criminal liability shall be held in parallel by both the legal manager and actual manager in case the food adulteration crime is committed in the name of legal person or for its account. In case the manager term expires, however he continues to manage this establishment and no other decision is issued to be temporarily remain in his office until he is replaced, in case a manager is unlawfully nominated, however he implements all management businesses and in case the persons who did not desire to be appeared as the establishment's legal managers for different reasons, especially when they are prevented from practicing the management right by virtue of a judgment or by law in case the law prohibits the combination of management and assuming certain jobs, they shall implement the management businesses hiding behind persons appeared as the establishment's managers appointed in return for the salaries they receive.

The provision ruled that whereas the decreelaw No. 95 of 1945AD is issued about the supply and the Article (58) hereof stipulates that the store's owner, manager or the person who supervises and manages the store shall be liable for the store violations, so the scope of liability proves the person's ownership or management to become litigated about this liability, regardless of the legal basis thereof either in reality or in virtuality. Thus, this person shall not be litigated in his capacity as manager when his management of the store is denied in a certain time when this violation occurs.

- Condition for proving the Manager's Criminal Liability:

First Condition, Food Adulteration Crime is committed by a Legal Person:

In order to prove the legal person's liability, the crime is committed for and on behalf thereof, i.e. this crime is committed to achieve its benefit either this benefit is material or moral, directly or indirectly. It is sufficient that the crime is committed to ensure the organization or workflow of the legal person's businesses or for the purpose of achieving its purposes. Consequently, the company selling the adulterated foods shall be liable for the food adulteration crime. Thus, the liability of actual manager who issues the order to sell and knows this adulteration crime shall be established and proven.

Second Condition, Natural Person's Violation of Duties:

In order to prove the liability of natural person for the actual management of food adulteration crime, this crime is committed as a result of the violation of his duties, i.e. he performs or refuses to perform his duties violating the legal or regulatory rules governing the legal person's workflow.

Third Condition, Knowledge of the Acts constituting the Food Adulteration Crime:

The person responsible for the actual management must know the acts constituting the food adulteration crime and the management shall tend to commit the same. Thus, his liability shall be denied in case the crime occurs as a result of negligence even if the act committed by him is deemed as a fatal error as the food adulteration crime is deemed as an intentional crime for which the intention pillar shall be established and proven.

Punishment stipulated by the legislator:

In accordance with the provision of the Article (65) of Penal Code, the punishments applied 
against the natural person responsible for the legal person's management shall be the same punishments applied against the original perpetrator of adulteration crime set out in the act issued to control both the adulteration and fraud of commercial transactions. These punishments shall range between imprisonment for a period not exceeding two years and a fine which shall not less than two hundred and fifty thousand dirhams and it shall not exceed one million dirhams or by one of both punishments.

However, the liability of the person responsible for the actual management shall be denied in case he proves that the crime occurs beyond his control. In this case, the punishment shall be limited to the default party and the manager's liability shall be also limited to the solidarity liability towards the settlement of sentenced fines.

The Person responsible for the actual management may deny his responsibility thereof as follows:

1. He proves that he complies with all law or regulatory rules and that he has no ability to prevent the occurrence of this crime.

2. He proves the impossibility of his control as a result of his absence or travel abroad as such matter shall prevent him from performing his control duties to prevent the occurrence of these violations.

3. In case he authorizes another person to supervise the adulterated production or another person shall be liable for this adulterated production.

In brief; in case the food adulteration crime is committed by the natural person who assumes the legal person's management for the account of latter himself, both his liability and the legal person's liability shall be proven and established.

However, this matter raises in case the adulteration acts are committed by an employee or a dependent of the legal person with no availability of the pillars of food adulteration crime towards the manager, an opinion sees that the criminal liability shall be held by the dependent solely and that both the manger's liability and legal person's liability shall not be proven and established because the dependent shall not be deemed as a representative of the legal person.
However, the Federal Court has another opinion about proving the legal person's liability for the adulteration crimes despite they are committed by an employee as it deems the capacities owned by the natural person as conditions for the duplicity of liability held by both the legal person and natural person. The provision ruled that in case the aforementioned capacities shall not be owned by the perpetrator of sinful act, but they shall be owned by the legal person's normal employee who shall not be deemed as its representative, manager or agent, such matter shall not prevent the legal person from being litigated, despite the natural person's innocence is proven in case any of the aforementioned capacities shall not be owned by him as he shall be deemed as a normal employee.

\section{Fourth Theme:} Punishments Applied against the Legal
Person for the Food Adulteration Crime

By inspecting the nature of legal persons, the stipulated punishments shall be consistent with their nature. These punishments shall vary as follows:

First, Punishments implied against the Financial Independence:

Punishments applied against the legal person's financial independence are those leading to the increase of their negative elements or decrease of their positive elements. Due to the nature of legal persons, the financial punishments shall successfully deter those persons either this deterrence is deemed as a special deterrence represented in the lack of recommitting the food adulteration crime or it is deemed as a general deterrence represented in the elimination of criminal motives of other legal persons. These punishments are represented in the fines and confiscations as follows:

\section{1- Fines}

The Article (14) of Act 19 of 2016AD issued to control commercial fraud stipulates that the fine punishment applied against the legal person shall not be less than two hundred fifty thousand dirhams and shall not exceed one million dirhams.

The legislator did not stipulate the application of relative fines against the legal person, despite they are effective in relation to 
achieving the punishment purposes as they are determined in accordance with the damages caused by the crimes, benefits achieved or intended to be achieved.

\section{2- Confiscation}

The confiscation shall represent one of the main and effective punishments to face the criminalization of legal persons as these punishments deprive them from the results of their crimes, i.e. the monies resulted from the food adulteration acts. The definitions mentioned about the confiscation discuss the expropriation of the things relating to the crime occurred or feared to occur to compensate its owner.

The Article (17) of Act 19 of 2016AD issued to control ommercial fraud stipulates that the confiscation punishment shall include the following:

1- The foodstuffs which are subject to adulteration.

2- The monies collected from dealing with the adulterated foodstuffs.

3- Equipment and machines used in the adulteration crime.

4- Things intended to be used in the adulteration crime in case the food adulteration crime is initiated to be committed.

Second, Punishment Applied against the Legal Person's Existence or Life (Dissolution of Legal Person):

The legal person's dissolution punishment is equivalent to the natural person's death penalty. In case it is necessary to deprive the person from the right to life, the dissolution is leading to the termination of legal person's legal existence whenever one of the legal entities violates the law.

Due to the gravity and severity of this punishment, the legislator stipulates that it shall be applied in case of recommitting the crime as the Article (20) of Act 19 of 2016AD issued on controlling commercial fraud stipulates that the court shall judge the cancellation of legal person's license in case the legal person recommits the food adulteration crime.

In other cases excluding recommitting the crime, the legal person is partially dissolved for a period not exceeding six months in accordance with the provision of Article (18) of Act issued to control commercial fraud, the section where the adulteration crime is committed or the part relating to the quality of adulterated goods shall be closed in case the legal person is a multi-sections store.

The punishment of establishment closure and license withdrawal shall be deemed as a moral punishment applied against the establishment itself and deemed also as an effective punishment applied to remove the disturbance effects occurred as a result of this crime and prevent its repetition in the future. Moreover, this punishment achieves the justice and restores the balance among the economic centers of similar establishments.

The Egyptian Court of Cassation said about the closure that the law stipulates that the store where the violation occurs shall be closed and it shall not be required to be owned by the person against which the punishment is applied for the crime he committed. Such matter shall not be objected alleging that this punishment is personal because the closure is not deemed as a punishment applied solely against the perpetrator, but also it is in fact deemed as a set of preventive actions which shall not prevent others from being influenced by their effects. The owner shall not be litigated in the case upon the closure decision is sentenced by the court whenever the judgment is issued based on that the perpetrator found in the store sentenced to be closed implements the duties and tasks assigned to him by his employer.

Third, Punishment applied against the Reputation (Publication of Judgment):

The Article (20) of Act 19 of 2016AD issued to control commercial fraud stipulates that the court shall order to publish the judgment, at the sentenced person's cost, in two local newspapers; one of both is issued in Arabic once the court is sentencing the condemnation about the food adulteration crime, i.e. the condemnation judgment is issued against the legal person sentenced to be guilty to be known by a greater number of society members so as not to work with him affecting on his activity and preventing him from committing these adulteration crimes.

\section{Research Recommendations}


Based on the abovementioned, we recommend the following:

First: The effective control of food adulteration crime shall require the establishment of criminal liability of legal persons due to the grand role played by the same in the economic life. The Emirati legislator is doing well when he explicitly stipulates that the legal persons are criminally liable for the food adulteration crime without the omission of this liability of the legal persons who are working for the legal person's account.

Second: The relative fine punishment shall be applied against the legal person for its effectiveness in relation to achieving the punishment purposes as it is determined in accordance with the damages caused by the crime, benefits achieved or intended to be achieved by the criminal for the purpose of preventing the criminalization motives of legal persons in relation to committing the food adulteration crime.

\section{Research Results}

By inspecting the previous presentation, we can say that the Emirati legislator has recognized the criminal liability of legal persons towards the food adulteration crime in parallel with the liability of natural person as the liability of natural persons who express the legal person's will and commit the adulteration acts in the name or for the account of this latter shall not be excluded and that the establishment of legal person's criminal liability is expanded by the Federal Court towards the criminal act without requiring certain capacity owned by the natural person who is working for him or who has a certain job. However, the Article (65) of Penal Code was obvious and clear about the necessity of availability of such matter to prove and establish the liability of legal person. Finally, the Emirati legislator is concerned with the application of punishments which fit with the nature of legal person.

\section{Conclusion}

We try in this research to apply some ideas about the criminal liability of legal persons for the food adulteration crime in the Emirati law as we explain and clarify the conditions for proving this liability as it is necessary that the committed act shall be included within the acts constituting the food adulteration crime, that the same crime shall be committed by one of the legal person's bodies or representatives and that the same crime shall be finally committed for the account and in the name of legal person. However, the criminal liability of legal person shall be proven and established in parallel with the natural person's liability to ensure the control of food adulteration crime so that the legal person's liability shall not constitute a veil to cover the liability of natural person for committing this criminal act. Moreover, it is logical to prove and establish the liability of legal person that the natural person who is working for his account and acting in his name is present. We also show the punishments including the punishments applied against the financial independence, existence, life and reputation of the legal person against which these punishments which shall fit with his nature shall be applied.

\section{List of References}

General Books:

1. Dr. Ahmed Fathy Sorour: Al-Waseet in Penal Code, General Section, Dar alNahda al-Arabiya 2016AD.

2. Dr. Hassan Sadeq Al Marsafawy: Al Marsafawy in Special Penal code, Monshaat Al Maaref in Alexandria.

3. Dr. Abdel Azim Morsi Wazir: Explanation of Penal Code, General Section, No Publishing House, 1996AD.

4. Dr. Abdel Raouf Mahdy: Explanation of General Rules of Penal Code, General Section, No Publishing House, 2003AD.

5. Dr. Abdel Raouf Mahdy: Criminal Liability for Economic Crimes in Comparative Law, Faculty of Law, Cairo University, 1974AD.

6. Dr. Aly Fadel Hassan: Theory of Confiscation in Comparative Criminal Law, Doctoral Thesis, Faculty of Law, Cairo University, 1977AD.

7. Dr. Maamon Salama: Explanation of Panel Code, General Section, Edition 2001AD.

8. Dr. Mahmoud Najeeb Hony: Explanation of Lebanese Penal Code, Halabi Rights Publications, Third Edition, 1998AD. 
Specialized Books:

2. Dr. Sherif Sayed Kamel: Criminal Liability of Legal Persons, Dar al-Nahda alArabiya, First Edition, 1997AD.

3. Dr. Abdel Azim Morsi Wazir: Conditions assumed to be applied against crime, Dar al-Nahda al-Arabiya, 1997AD.

4. Dr. Abdel Azim Morsi Wazir: Consumer Protection under Economic Penal Code in Egypt, Journal of Law and Economics, Faculty of Law, Cairo University, 1983AD.

5. Dr. Adbulrazaq Al Muwafy: Criminal Liability of Economic Establishment's Manager, Doctoral Thesis, Faculty of Law, Mansoura University, 1999AD.

6. Dr. Mahmoud Mahmoud Mustafa: Economic Crimes in Comparative Law, Part I, General Provisions and Criminal Procedures, Cairo University, Second Edition, 1979AD.

7. Dr. Aly Fadel Hassan: Theory of Confiscation in Comparative Criminal Law, Doctoral Thesis, Faculty of Law, Cairo University, 1977AD.

\section{Judgments:}

- Set of Judgments issued by the Egyptian Court of Cassation.

- Set of Judgments issued by the Supreme Federal Court.

- Set of Judgments issued by Dubai Court of Cassation.

- Set of Judgments issued by Abu Dhabi Court of Cassation.

\section{Bibliography}

- Dr. Mohamed Najeeb Hosny: Explanation of Lebanese Penal Code, General Section, Halabi Rights Publications, Third Edition, 1998AD, p. 664 and 665, para. 470.

- Dr. Sherif Sayed Kamel: Criminal Liability of Legal Persons, Dar al-Nahda alArabiya, First Edition, 1997AD, p. 6, para. 1.

- Dr. Abdel Azim Morsi Wazir: Consumer Protection under Economic Penal Code in Egypt, Journal of Law and Economics, Faculty of Law, Cairo University, 1983AD, p. 3.
- (Law No. 19 of 2016AD is issued to control Commercial Fraud dated 12/12/2016AD and promulgated in the Official Gazette No. 609 of the year 46 dated 15/12/2016AD).

- Dr. Mahmoud Mahmoud Mustafa: Economic Crimes in Comparative Law, Part I, General Provisions and Criminal Procedures, Cairo University, Second Edition, 1979AD, p. 135, para. 81. Dr. Abdel Raouf Mahdy: Criminal Liability for Economic Crimes in Comparative Law, Faculty of Law, Cairo University, 1974AD, p. 481 , para. 303 .

- Federal Supreme Court: Appeal No. 41 of 28 Judicial, J. 65, Hearing dated $18 / 12 / 2006$ AD, Set of the Judgments issued by the Federal Supreme Court Circuits of Penal and Shari'a Jurisdictions Circuits, Year: Twenty-Eighth (2006AD), as of $1^{\text {st }}$ of January to the End of December, United Arab Emirates University Publications.

- Dubai Court of Cassation: Appeal No. (49) of Year 2003AD and (68) of 2003AD, J. 16, Hearing dated 29/3/2003AD, Set of Judgments issued by the Technical Office, $14^{\text {th }}$ Issue (Criminal), Part II, 2003AD, p. 84.

- Federal Law No. (2) of 2015AD on Commercial Companies authorizes the Establishment of both the Limited Liability Company consisted of One Person and Private Joint Stock Company, as the Article 8/3 stipulates that as Exemption from Clause (1) of this Article, a Company may be established or owned by One Person in accordance with the Provisions of this Law.

- Dubai Court of Cassation: Appeal No. (49) of 2003AD and Appeal No. (68) of 2003AD, J. 16, Hearing dated 29/3/2003AD, Set of Judgments issued by the Technical Office, $14^{\text {th }}$ Issue (Criminal), Part II, 2003AD, p. 84.

- Dr. Adbulrazaq Al Muwafy: Criminal Liability of Economic Establishment's Manager, Doctoral Thesis, Faculty of Law, Mansoura University, 1999AD, p. 469, para 287.

- Dr. Ahmed Fathy Sorour: Al-Waseet in Panel Code, General Section, Dar al- 
Nahda al-Arabiya, Sixth Edition, 1996AD, p. 489 , para. 326 .

- Dr. Sherif Sayed Kamel: Previous Reference, p. 118.

- Federal Supreme Court: Appeal No. 41 of 28 Judicial, J. 65, Hearing dated $18 / 12 / 2006 \mathrm{AD}$, Set of Judgments issued by the Federal Supreme Court Circuits of Penal and Shari'a Jurisdictions Circuits, Year: Twenty-Eighth (2006AD), as of $1^{\text {st }}$ of January to the End of December, United Arab Emirates University Publications.

- Abu Dhabi Court of Cassation: Appeal No. 105 of 2008AD, S2 J.A, Judicial 105, Hearing dated 16/7/2008AD, Set of Judgments and legal principles issued by Court of Cassation, Penalties Circuit, Second Judicial Year, 2008AD, as of $1^{\text {st }}$ of January to the end of December, p. 515.

- Dr. Adbulrazaq Al Muwafy: Previous Reference, p. 473, para. 292.

- Dr. Sherif Sayed Kamel: Previous Reference, p. 123.

- Dr. Adbulrazaq Al Muwafy: Previous Reference, p. 413, para. 261.

- Egyptian Court of Cassation, January 26, 1970AD, Set of Cassation Judgments, S21,p 187, No. 46.

- Article (14) of the Act issued to control Commercial Fraud under No. 19 of 2016AD.

- Dr. Hosny Al Jendy: Previous Reference, p. 196.

- Dr. Adbulrazaq Al Muwafy, Previous Reference, p. 479, para 297.

- Previous Reference, Previous Place.

- Supreme Federal Court, Appeal No. 41 of 28 Judicial, J 65, Hearing of $18 / 12 / 2006 \mathrm{AD}$, Set of the Judgments issued by the Supreme Federal Court Circuits of Penal and Shari'a Jurisdiction
Circuits, Year: Twenty-Eighth (2006AD) as of $1^{\text {st }}$ of January to the End of December, United Arab of Emirates Publications.

- Dr. Omar Salem: Criminal Liability of Legal Persons, Dar al-Nahda al-Arabiya, First Edition, 1995, p. 24, para. 49.

- Dr. Aly Fadel Hassan: Theory of Confiscation provided for in Comparative Criminal Law, Doctoral Thesis, Faculty of Law, Cairo University, 1977AD, p. 65. Dr. Fawziah Abdulsattar: Explanation of AntiDrugs Act, Dar al-Nahda al-Arabiya, 1990AD, p. 98. Dr. Abdel Raouf Mahdy: Explanation of General Rules of Penal Code, Previous Reference, p. 708.

- Dr. Abdel Azim Morsi Wazir: Explanation of Penal Code, General Section, Part II, General Theory of Punishment, No Publishing House, 1994AD, p. 52, para. 33.

- The Article (82) of Federal Penal Code Amended by Law No. 7 of 2016AD stipulates that the Court sentenced, upon judging condemnation, to confiscate the seized things and monies which are used, intended to be used or obtained from crime. In case it is impossible to seize these things or monies, a fine equivalent to its value is sentenced by the court, without prejudice to the rights of others in accordance with their good faith.

- Dr. Mahmoud Najeeb Hosny: Previous Reference p. 517, para. 558.

- Dr. Fayezah Youness Al-Basha: Organizing Crime in light of International Agreements and National Laws "Comparative Study", Faculty of Law, Cairo University, 2001AD, p. 333.

- Dr. Mahmoud Mahmoud Mustafa: Previous Reference p. 168, para. 112.

- Egyptian Court of Cassation 22/12/1947AD, Set of Legal Rules, Part 7, p. 436 , No. 469. 